\title{
The effects of different doses of caffeine on performance, rating of perceived exertion and pain perception in teenagers female karate athletes
}

\author{
Hamid Arazi $^{1 *}$, Marzieh Hoseinihaji ${ }^{2}$, Ehsan Eghbali ${ }^{1}$ \\ ${ }^{1}$ Department of Exercise Physiology, Faculty of Sport Sciences, University of Guilan, Rasht, Iran, ${ }^{2}$ Department of Sport \\ Sciences, Islamic Azad University, Science and Research Branch, Rasht, Iran
}

\begin{abstract}
The present study set to examine the effects of different doses of caffeine on performance, rating of perceived exertion (RPE), and pain perception in female teenager athletes of karate. Ten female karate athletes $\left(16.8 \pm 1.23\right.$ years; height $1.59 \pm 0.28 \mathrm{~m}$; body-mass $57.73 \pm 8.33 \mathrm{~kg}$; BMI $\left.22.71 \pm 3.05 \mathrm{~kg} / \mathrm{m}^{2}\right)$ participated in the study. A double-blind, randomized, and crossover counterbalanced design was used. In three sessions (with an interval of seven days'), ten female karate athletes ingested low dose (2 mg/ $\mathrm{kg})$, moderate dose $(5 \mathrm{mg} / \mathrm{kg}$ ) caffeine, and placebo. Sixty minutes after consumption, they performed the tests as below: one repetition maximum and $60 \%$ of one repetition maximum in the leg press, explosive power test, and anaerobic RAST test. After the tests, the participants' RPE (6-20 scale) and pain perception $(0-10$ scale) were recorded using various categorical scales. The results showed that caffeine ingestion at moderate dose significantly reduced RPE and pain perception values compared with the placebo during muscular endurance test $(\mathrm{P}=0.0001$ and $\mathrm{P}=0.039$, respectively). The findings suggest that caffeine dose of $5 \mathrm{mg} / \mathrm{kg}$ body mass appears to improve RPE and pain perception in female teenager athletes of karate. The dose of $2 \mathrm{mg} / \mathrm{kg}$ body mass does not confer any additional improvement in performance.
\end{abstract}

Uniterms: Caffeine/effects. Karate athletes/performance. Caffeine/rating of perceived exertion. Caffeine/ performance. Caffeine/pain perception.

\section{INTRODUCTION}

Caffeine (1,3,7-trimethylxanthine) is a plant alkaloid that occurs naturally in the diet (Sökmen et al., 2008) and nearly $90 \%$ of US adults consume caffeine in forms of coffee, tea, or other caffeinated food products ( 8 cup of coffee may contain 50-200 mg caffeine) (Owens, 2015; Yang, Palmer, De Wit, 2010). In the U.S.A., adults ingest an average of $3 \mathrm{mg} / \mathrm{kg}$ of caffeine daily in coffee, tea, caffeinated sodas, and many other drinks and food (Sökmen et al., 2008). The popularity of caffeine as an ergogenic aide has increased dramatically over the last decade (Hendrix et al., 2010), Caffeine is the most widely consumed to improve cognitive, physical performance during exercise and has become a popular ergogenic aid

\footnotetext{
*Correspondence: H. Arazi. Department of Exercise Physiology. Faculty of Sport Sciences. University of Guilan. P.O.Box: 1438 - Rasht, Iran. E-mail: hamidarazi@yahoo.com
}

among recreational and competitive athletes (Hendrix et al., 2010; Sökmen et al., 2008; Zheng et al., 2014).

Caffeine is classified as part of the methylxanthine family of drugs (Cechella et al., 2014; Mohr, Nielsen, Bangsbo, 2011) and is extensively consumed by athletes as an ergogenic aid (Backhouse et al., 2011; Mohr, Nielsen, Bangsbo, 2011) since its removal from the World AntiDoping Agency (WADA) prohibited list of substances (Backhouse et al., 2011; Mohr, Nielsen, Bangsbo, 2011). According to the Medical Council of International Olympic Committee (IOC), caffeine is allowed in sports as long as its urinary excretion level is below $12 \mu \mathrm{g} / \mathrm{mL}$ (Bell, Jacobs, Ellerington, 2001).

Taken orally, caffeine reaches a peak plasma concentration of 30-90 min after ingestion, and a halflife has been reported to be 3 to 5 hours with a modest intake of coffee (Sökmen et al., 2008; Spriet, 2014), but longer when the dose exceeds $300 \mathrm{mg}$; this value may vary among acute and chronic users (Sökmen et al., 2008). 
Plasma caffeine levels rise to $15-20 \mu \mathrm{mol} / \mathrm{L}$ with a low caffeine dose $(3 \mathrm{mg} / \mathrm{kg}), 40 \mu \mathrm{mol} / \mathrm{L}$ with a moderate dose $(6 \mathrm{mg} / \mathrm{kg})$, and $60-70 \mu \mathrm{mol} / \mathrm{L}$ with a high dose of $9 \mathrm{mg} /$ $\mathrm{kg}$ (Spriet, 2014). Caffeine is metabolized by the liver and through enzymatic action (in 6 to 7 hours, $75 \%$ of caffeine is cleared from the body), resulting in three metabolites: paraxanthine, theophylline, and theobromine (Goldstein et al., 2010; Sökmen et al., 2008).

Researches that have examined the role of caffeine supplementation in endurance, high-intensity, or strength on trained women are scant, especially in comparison with men (Goldstein et al., 2010). Also, the ability of caffeine to reduce (ratings of perceived exertion) RPE and pain perception during exhaustive exercise needs to be clarified in women athletes (Astorino, Roupoli, Valdivieso, 2012). Doherty and Smith(2005) revealed that moderate to high caffeine doses $(4-10 \mathrm{mg} /$ $\mathrm{kg}$ ) ingested 30-90 min before exercise reduce RPE. However, others have shown that caffeine does not influence RPE and pain perception. Jenkins et al. (2008) showed that caffeine ingestion ( 2 and $3 \mathrm{mg} / \mathrm{kg}, 60 \mathrm{~min}$ before performance) does not influence reductions of perceived effort and leg-muscle pain. In addition, Warren et al. (2010) demonstrated that caffeine ingestion (1-9 $\mathrm{mg} / \mathrm{kg}$ ) improves maximal voluntary contraction strength and muscular endurance. Astorino et al. (2011a) reported that caffeine consumption $(6 \mathrm{mg} / \mathrm{kg})$ before exercise $(60$ min) has significant effect on leg press performance. However, in another study, it was shown that ingestion of caffeine has no effect on 1RM strength and muscular endurance (Astorino, Rohmann, Firth, 2008; Beck et al., 2006).

With regard to the effects of caffeine, probably it can influence performance indicators of karate athletes, but these effects are certainly not clear. Karate requires a high level of physical, physiological, complex technical skills, and tactical excellence for success (Tabben et al., 2013). The physiological characteristics of athletes are generally measured by testing their fitness and skill components (Chaabène et al., 2012). The fitness components usually include aerobic fitness, muscular strength, muscular endurance, flexibility, and speed (Chaabène et al., 2012; Tabben et al., 2013). Modern karate consists of numerous repetitions of high intensity actions per fight lasting 1-3s each, separated by low-intensity hopping-stepping movements $(18 \pm 6 \mathrm{~s}$,$) and short referees breaks ( 9 \pm 6 \mathrm{~s})$ (Tabben et al., 2013).

The current study examined whether $2 \mathrm{mg} / \mathrm{kg}$ and $5 \mathrm{mg} / \mathrm{kg}$ caffeine ingestion would improve performance, rating of perceived exertion, and pain perception in female teenager athletes of karate compared to the placebo.

\section{MATERIAL AND METHODS}

\section{Participants}

Ten teenagers female karate athletes (Mean $\pm \mathrm{SD}$; age $16.8 \pm 1.23$ years; height $1.59 \pm 0.28 \mathrm{~m}$; body-mass $57.73 \pm 8.33 \mathrm{~kg}$; BMI $22.71 \pm 3.05 \mathrm{~kg} / \mathrm{m}^{2}$ ) volunteered to participate in the study. All participants had previous karate experience of at least 3 years and had trained for 3-4 days/week during the previous year. All participants were light caffeine consumers (not more than one coffee or one serving of energy drink per day). Participants underwent a physical examination prior to enrolling in the study and they were light caffeine consumers $(<60 \mathrm{mg} /$ day, and 1 cup of coffee). Participant no had a previous history of cardiopulmonary disease or was taking medications during the study. Each participant and his parent/guardian were informed of the experimental procedures and associated risks of the investigation and an informed consent was signed by the both of them. The University ethics committee approved the study protocol.

\section{Experimental design}

A double-blind, randomized, and crossover counterbalanced design was used. Each player performed three experimental trials under the same environmental conditions $\left(28 \pm 1{ }^{\circ} \mathrm{C} ; 87 \pm 5 \%\right.$ relative humidity). On the first session, players ingested $2 \mathrm{mg} / \mathrm{kg}$ caffeine provided in gelatin capsules. The amount of caffeine was individually set to provide a dose of $2 \mathrm{mg}$ of caffeine per $\mathrm{kg}$ of body mass. On the second session, the participants ingested placebo capsules filled with the same amount of dextrose to avoid identification ( $0 \mathrm{mg} / \mathrm{kg}$; placebo, contain farina). On the third session, players ingested $5 \mathrm{mg} / \mathrm{kg}$ caffeine. Training sessions with an interval of seven days were performed. The capsules were ingested $60 \mathrm{~min}$ before the testing protocol because it was repeatedly reported that blood caffeine concentration peaks 30-60 min after ingestion.

\section{Experimental protocol}

Two days before the first trial, athletes were nude-weighed to calculate the energy drink dosage. Furthermore, the participants were encouraged to refrain from all dietary sources of caffeine (coffee, cola drinks, chocolate etc) for $48 \mathrm{~h}$ before testing. The day before each trial, the participants refrained from strenuous exercise and adopted a similar diet and fluid intake regimen. Food and fluid diaries were obtained to ensure compliance. The 


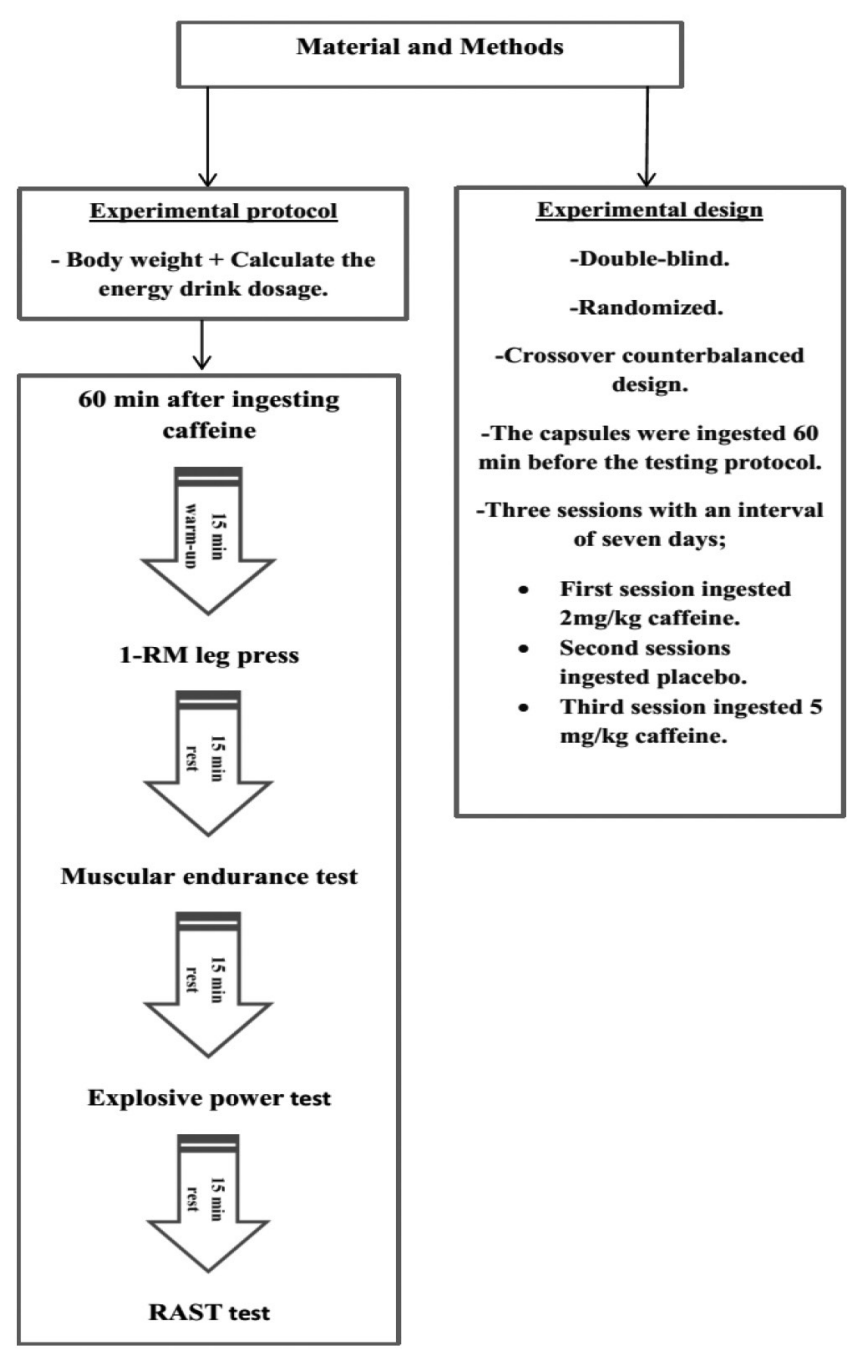

FIGURE 1 - Study design.

participants were in a fasted state $12 \mathrm{~h}$ before the beginning of each session (Mora-Rodríguez et al., 2012).

The tests were performed approximately $60 \mathrm{~min}$ after ingesting gelatin capsules containing either $2 \mathrm{mg} / \mathrm{kg}$ of caffeine, equivalent dose of a placebo, and $/$ or $5 \mathrm{mg} / \mathrm{kg}$ of caffeine with $200 \mathrm{~mL}$ of water in each session. The dose of caffeine or placebo was weighed and placed in opaque gelatin capsules. Before the tests, the participants completed a standardized dynamic warm-up lasting $15 \mathrm{~min}$, including a brief unloaded sprint to be prepared for subsequent tests. After the warm-up, the participants performed the test.

Determination of one repetition maximum (1-RM) in the leg press was ensued according to the methods of Brzycki (1993). 1-RM in the leg press represented the maximum weight lifted once with proper form and was calculated using the formula of Brzycki (1993).

$$
1 \mathrm{RM}=\text { load } /\left(\begin{array}{c}
1.0278-0.0278 \text { (number of repetition to } \\
\text { exhaustion) })
\end{array}\right.
$$

After 1-RM determination and 15 min rest, muscular endurance test with $60 \%$ of one repetition maximum in the leg press exercises was performed. $60 \%$ of $1-\mathrm{RM}$ was placed on the bar to measure muscular endurance, and the participants completed repetitions to failure (Astorino, Rohmann, Firth, 2008). Moreover, to evaluate the explosive power of the lower body, vertical jump (Sargent) was performed. In addition, the RAST (Runningbased Anaerobic Sprint Test) test was performed after a 15-minute rest (Mora-Rodríguez et al., 2012), consisting of six repetitions at a distance of $35 \mathrm{~m}$. And the maximum intensity is a quick run with $10 \mathrm{~s}$ rest between each repetition (recorded during the test by a timer $0.01 \mathrm{sec}$ ); it was calculated using the following formula:

$$
\begin{aligned}
& \text { Peak anaerobic power }=\text { weight }(\mathrm{kg}) \times 35^{2} / \\
& \text { repeated fastest time }
\end{aligned}
$$

The participants filled out Borg RPE scale and pain perception after the tests (Brunyé et al., 2010; Cook et al., 1997; Cook et al., 1998). Pain perception was measured using a $0-10$ categorical scale with ratio properties after $1 \mathrm{RM}$ leg press, $60 \% 1 \mathrm{RM}$ leg press, Sargent test, and RAST test $(0=$ no pain at; $10=$ extremely intense pain (almost unbearable) (Cook et al., 1997; Cook et al., 1998). After termination of the tests, experimenters held up the scale, and the participants were asked to report their pain perception at that instant. Also, muscle ratings of perceived exertion were assessed via the standard Borg RPE scale (Borg, 1973); 6-20 category ratio scale was explained to the participants, and the instructions were repeated during subsequent trials (Borg, 1973). At the end, the experimenters held up the scale and the participants reported their RPE at that instant, representing total-body exertion. The participants were previously informed that 6 points meant minimal amount (no exertion) of that item, and 20 points meant maximal amount (maximal exertion) of the item. The participant returned one week later and repeated the identical protocol after ingestion of other dosage of caffeine or placebo.

\section{Statistical analysis}

Data are expressed as mean \pm standard deviation (SD). Statistical analysis was performed using a oneway analysis of variance (ANOVA). If a significant $F$ ratio was obtained, Tukey's post hoc test was used to detect significant differences between means. Significant differences were determined based on an alpha level of less than 0.05. All statistical analyses were performed using SPSS 20.0. 


\section{RESULTS}

In comparison to the low dose caffeine and placebo, the pre-exercise ingestion of the moderate dose caffeine, lower $\mathrm{RPE}(\mathrm{P}=0.002$ and $\mathrm{P}=0.0001$ respectively), and in comparison to the placebo, the pre-exercise ingestion of the moderate dose caffeine, lower pain perception during muscular endurance test ( $\mathrm{P}=0.039)$ (Figures 2 and 3 ).

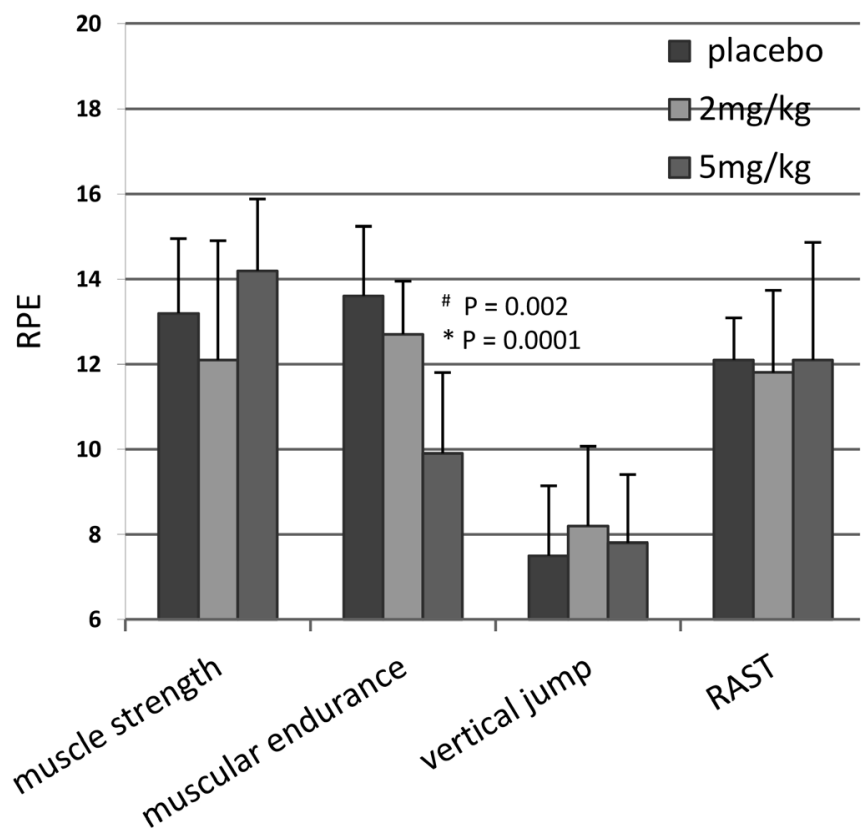

FIGURE 2 - Mean \pm SD of RPE after the tests. * Significant differences $(\mathrm{P}<0.05)$ compared to placebo. \# Significant differences $(\mathrm{P}<0.05)$ compared to low dose caffeine $(2 \mathrm{mg} / \mathrm{kg})$. RPE: ratings of perceived exertion; RAST: Running-based Anaerobic Sprint Test.
However, no significant difference was observed in the ingestion of different doses of caffeine in RPE and pain perception on other tests (Figures 2 and 3 ). In addition, the low dose and moderate dose caffeine did not affect the muscle strength and muscular endurance of the leg press (Table I). Similarly, the ingestion of different doses of caffeine did not increase explosive power and anaerobic power during the vertical jump and RAST test (Table I).

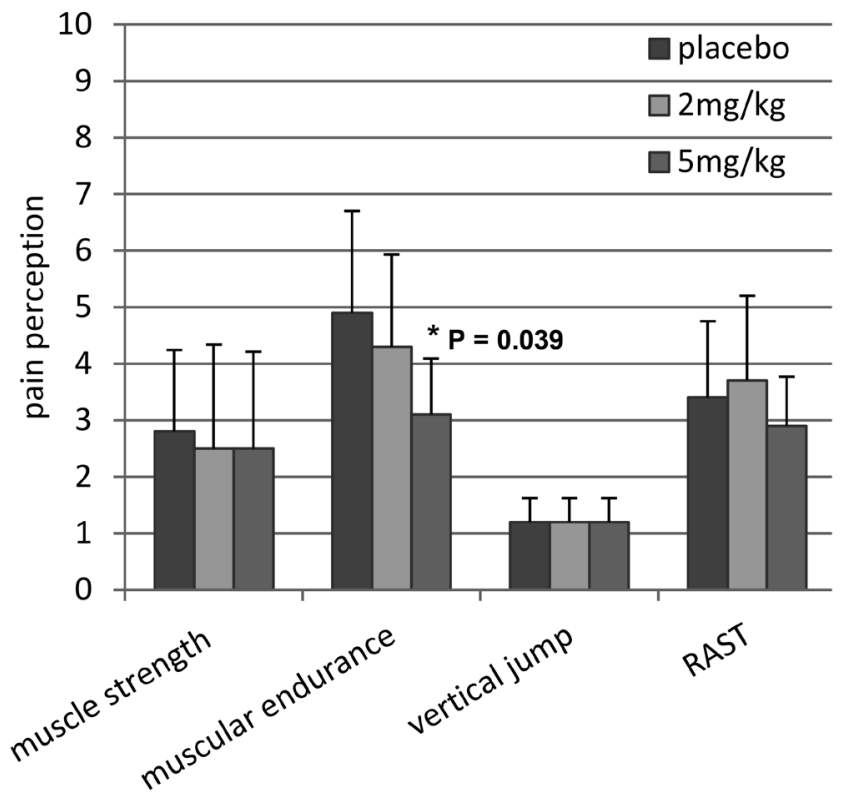

FIGURE 3 - Mean \pm SD of pain perception after the tests. * Significant differences $(\mathrm{P}<0.05)$ compared to placebo. RAST: Running-based Anaerobic Sprint Test.

TABLE I - The mean and standard deviation of the measured variables between different doses of caffeine and placebo

\begin{tabular}{lccc}
\hline Variable & & Mean \pm SD & p \\
\hline & placebo & $154 \pm 27.3$ & 0.10 \\
Muscular strength (leg press) (kg) & $2 \mathrm{mg} / \mathrm{kg}$ & $171 \pm 15.90 .10$ & \\
& $5 \mathrm{mg} / \mathrm{kg}$ & $156 \pm 20.6$ & 0.63 \\
Muscular endurence (leg press) (repetition) & $\mathrm{placebo}$ & $46 \pm 15.7$ & \\
& $2 \mathrm{mg} / \mathrm{kg}$ & $47 \pm 22.6$ & 0.15 \\
Lower body explosive power (vertical jump) (cm) & $5 \mathrm{mg} / \mathrm{kg}$ & $39 \pm 26.5$ & \\
& $\mathrm{placebo}$ & $29 \pm 3.76$ & 0.17 \\
& $2 \mathrm{mg} / \mathrm{kg}$ & $29 \pm 5.9$ & \\
\hline & $5 \mathrm{mg} / \mathrm{kg}$ & $33 \pm 4.6$ & $186 \pm 79.8$ \\
\hline
\end{tabular}




\section{DISCUSSION}

The current study examined the effect of different doses of caffeine on performance, rating of perceived exertion, and pain perception in female teenager athletes of karate. The results showed that consumption of 5 $\mathrm{mg} / \mathrm{kg}$ caffeine compared with placebo reduced RPE and perceptions of pain after muscular endurance test, which is in agreement with a range of preceding studies (Backhouse et al., 2011; Doherty, Smith, 2005; Duncan et $a l ., 2013$ ) and is contrast to studies reporting no significant reductions of RPE and perceptions of pain after tests following acute caffeine ingestion (Astorino et al., 2011b; Astorino, Roupoli, Valdivieso, 2012).

Studies suggest that caffeine ingestion reduces RPE and perceptions of pain. In a review article, Doherty and Smith (2005) reviewed 21 studies and revealed moderate to high caffeine doses $(4-10 \mathrm{mg} / \mathrm{kg})$ ingested $30-90 \mathrm{~min}$ before exercises reduced RPE obtained during submaximal aerobic exercise versus placebo. Also, Duncan et al. (2013) and Backhouse et al. (2011) demonstrated that moderate dose $(6 \mathrm{mg} / \mathrm{kg})$ of caffeine ingested $1 \mathrm{~h}$ prior to exercise was associated with a maintenance effect in relation to feelings of pleasure and lowered perceptions of effort and RPE reduction. The study of Duncan et al. (2013) showed that RPE was significantly lower during upper body exercises compared to lower body exercises. Also, muscle pain perception was lower in the caffeine condition, irrespective of exercise.

Caffeine is one of the oldest stimulants known to mankind and it has been argued that its most pronounced effects are evident in delaying the onset of fatigue (Backhouse et al., 2011). Multiple mechanisms might be responsible for reduce RPE in exercise. Caffeine increases the activation of the sympathetic central nervous system through adenosine receptor antagonism (Davis, Green, 2009) thus, caffeine is in blocking the inhibitory properties of endogenous adenosine (particularly at $A_{1}$ and $\mathrm{A}_{2 \mathrm{~A}}$ receptors), resulting in increased behaviors related to dopamine, norepinephrine and glutamate release (Brunyé et al., 2010; Lorist, Tops, 2003). Adenosine inhibits the release of most excitatory neurotransmitters in the brain, particularly dopamine, and might reduce dopamine synthesis (Woolf, Bidwell, Carlson, 2008). Adenosine A1 receptors are present in almost all brain areas (The highest levels are found in the hippocampus, cerebral and cerebellar cortex, and certain thalamic nuclei) (Lorist, Tops, 2003), caffeine might inhibit adenosine from blocking neuronal transmission and thus alter perception of pain, alertness, wakefulness (Brunyé et al., 2010), sympathetic activity, motor recruitment, and fatigue
(Woolf, Bidwell, Carlson, 2008). The results, caffeine might also increase time to exhaustion. Because caffeine is a dopamine agonist increased dopamine release (Brunyé et al., 2010), it could possibly reduce RPE (Woolf, Bidwell, Carlson, 2008).

In contrast, Astorino et al. (2011b) and Astorino, Roupoli, Valdivieso (2012) not altering demonstrated RPE, pain perception, on influence ingested moderate dose $(6 \mathrm{mg} / \mathrm{kg})$ and $2-5 \mathrm{mg} / \mathrm{kg}$ caffeine $1 \mathrm{~h}$ before cycling performance and high-intensity exercise on active women and men (Astorino, Roupoli, Valdivieso, 2012). Also, carbohydrate availability does not limit functions during exercise less than one hour as completed, so caffeine may not alter RPE during activities in which glycogen depletion does not occur (Astorino, Roupoli, Valdivieso, 2012). Additionally, habitual intake caffeine, the type of muscle actions performed and moreover the 0-10 RPE scale may lack adequate sensitivity to detect small alterations in perception during activity (Astorino, Roupoli, Valdivieso, 2012).

Caffeine by facilitate neuromuscular function at the level of the sarcoplasmic reticulum via release calcium (Ca) on sarcoplasmic reticulum (Davis, Green, 2009; Machado et al., 2010) and caffeine's direct antagonism of adenosine receptors (widely present in human tissue including the brain, skeletal muscle and adipose tissue) (Tarnopolsky, 2010) on the skeletal muscle membrane to enhance excitation-contraction coupling via a greater release of $\mathrm{Ca}$ from the sarcoplasmic reticulum and or facilitating $\mathrm{Na} / \mathrm{k}$ ATPase pump activity (Hendrix et al., 2010). Also, adenosine antagonism in adipocytes clearly leads to increased lipolysis and an increase in plasma free fatty acid (FFA) concentration (Glaister et al., 2014; Tarnopolsky, 2010). Additionally, compared with fast twitch fibers, caffeine may have a greater sensitivity for affecting slow twitch muscle fibers and slow twitch sarcoplasmic reticulum (Davis, Green, 2009). Caffeine increase intracellular cyclic adenosine monophosphate (c-AMP) by phosphodiesterase inhibition (Tarnopolsky, 2010). Increase in c-AMP would lead to a greater lipolysis, and relationship with regulation of adipose tissue (Davis, Grenn, 2009).

Our findings are in line with a number of studies showing no improvement in muscular endurance and muscular strength following caffeine intake (Astorino, Rohmann, Firth, 2008; Beck et al., 2006; Hendrix et al., 2010). Beck et al. (2006) showed that supplements containing caffeine do not affect muscular endurance (bench press, leg extension) and leg extension 1RM (muscular strength). Astorino, Rohmann, Firth (2008) reported that ingestion of $6 \mathrm{mg} / \mathrm{kg}$ dose of caffeine taken 
$1 \mathrm{~h}$ before had no effect on 1RM strength and muscular endurance (bench press, leg press) in resistance-trained men.

However, in two met analyses, Warren et al. (2010) and Spriet (2014) reported that caffeine ingestion improves MVC (Maximum Voluntary Contraction) strength and muscular endurance. Warren et al. (2010) examined 34 studies and revealed that caffeine ingestion $(1-9 \mathrm{mg} / \mathrm{kg})$ improves knee extensor MVC strength and muscular endurance only when it is assessed with open end point tests. Spriet (2014) found that moderate to high caffeine doses $(5-13 \mathrm{mg} / \mathrm{kg})$ ingested $1 \mathrm{~h}$ before and during exercise increase endurance exercise performance in laboratory and sport field settings. In a follow-up, Astorino et al. (2011a) gave $6 \mathrm{mg} / \mathrm{kg}$ caffeine $60 \mathrm{~min}$ before exercise (completion of four sets of barbell bench press, leg press, and bilateral row) to resistant trained men who were regular caffeine consumers, showing a significant effect of acute caffeine ingestion on leg press performance.

The differences between our results and previous studies are due to caffeine dosages, the type of muscle actions performed, the characteristics and fitness level of the study subjects. Also, considering the ergogenic benefits of caffeine directly on skeletal muscle (Tarnopolsky, 2010; Woolf, Bidwell, Carlson, 2008), elite athletes generally have more muscle mass than recreational athletes; also, women have less muscle mass than men. The effect of caffeine would be greater in individuals with a larger muscle mass (Woolf, Bidwell, Carlson, 2008). Accordingly, it seems that the effect of caffeine on performance of women is less than men, and these possibly explain the differences in results.

In the current findings, no significant difference was observed regarding the consumption caffeine on anaerobic power. Beck et al. (2006) indicated that consumption of caffeine had no effect on mean power, compared to the placebo.

Two studies suggested that caffeine supplementation $(5 \mathrm{mg} / \mathrm{kg}) 1 \mathrm{~h}$ before exercise significantly increases power output (Glaister et al., 2014; Woolf, Bidwell, Carlson, 2008). The subjects in a study were male students of strength and conditioning and sport science and trained competitive male athletes; the performance task was cycle ergometer sprints, and $30 \mathrm{~s}$ Wingate test was conducted (Glaister et al., 2014; Woolf, Bidwell, Carlson, 2008). It seems that caffeine consumption in events that heavily rely on the glycolytic system ( $15 \mathrm{~s}$ to $3 \mathrm{~min}$ ) has no positive impact on performance (possibly because of increase in plasma ammonia levels and decrease in intracellular pH) (Greer, McLean, Graham, 1998; Sökmen et al., 2008). Also, it is indicated that the sensitivity of caffeine consumers to the performance enhancing effects of caffeine is related to habitual intake (Woolf, Bidwell, Carlson, 2008). Moreover, the rate of caffeine metabolism varies widely among individuals due to variability in the hepatic CYP1A2 enzyme which causes different responses to caffeine (Owens, 2015).

In summary, the present study demonstrated that ingestion of a moderate dose of caffeine $(5 \mathrm{mg} / \mathrm{kg})$ reduced RPE and pain perception in female teenager athletes of karate, however, having no influence on performance. Also, the ingestion of a small dose of caffeine $(2 \mathrm{mg} / \mathrm{kg})$ did not have any effect on performance, RPE, and pain perception.

\section{ACKNOWLEDGEMENTS}

We would like to thank the karate athletes for their cooperation and contributions to this study.

\section{CONFLICT OF INTERESTS}

None

\section{REFERENCES}

ASTORINO, T.A.; ROHMANN, R.L.; FIRTH, K. Effect of caffeine ingestion on one-repetition maximum muscular strength. Eur. J. Appl. Physiol., v.102, n.2, p.127-132, 2008.

ASTORINO, T.A.; MARTIN, B.J.; SCHACHTSIEK, L.; WONG, K. N.G. K. Minimal effect of acute caffeine ingestion on intense resistance training performance. $J$. Strength Cond. Res., v.25, n.6, p.752-1758, 2011a.

ASTORINO, T.A.; TERZI, M.N.; ROBERSON, D.W.; BURNETT, T.R. Effect of caffeine intake on pain perception during high-intensity exercise. Int. J. Sport. Nutr. Exerc., v.21, n.1, p.27-32, $2011 b$.

ASTORINO, T.A.; ROUPOLI, L.R.; VALDIVIESO, B.R. Caffeine does not alter RPE or pain perception during intense exercise in active women. Appetite, v.59, n.2, p.585-590, 2012.

BACKHOUSE, S.H.; BIDDLE, S.J.; BISHOP, N.C.; WILLIAMS, C. Caffeine ingestion, affect and perceived exertion during prolonged cycling. Appetite, v.57, n.1, p.247-252, 2011. 
BECK, T.W.; HOUSH, T.J.; SCHMIDT, R.J.; JOHNSON, G.O.; HOUSH, D.J.; COBURN, J.W.; MALEK, M.H. The acute effects of a caffeine-containing supplement on strength, muscular endurance, and anaerobic capabilities. J. Strength Cond. Res., v.20, n.3, p.506-510, 2006.

BELL, D.G.; JACOBS, I.; ELLERINGTON, K. Effect of caffeine and ephedrine ingestion on anaerobic exercise performance. Med. Sci. Sport. Exerc., v.33, n.8, p.13991403, 2001.

BORG, G.A. Perceived exertion: a note on" history" and methods. Med. Sci. Sport. Exerc., v.5, n.2, p.90-3, 1973.

BRUNYÉ, T.T.; MAHONEY, C.R.; LIEBERMAN, H.R.; TAYLOR, H.A. Caffeine modulates attention network function. Brain Cognit., v.72, n.2, p.181-188, 2010.

BRZYCKI, M. Strength testing-predicting a one-rep max from reps-to-fatigue. J. Phys. Edu. Rec. Dan., v.64, n.1, p.88-90, 1993.

CECHELLA, J.L.; LEITE, M.R.; DOBRACHINSKI, F.; DA, ROCHA. J.T; CARVALHO, N.R.; DUARTE, M.M.; ZENI, G. Moderate swimming exercise and caffeine supplementation reduce the levels of inflammatory cytokines without causing oxidative stress in tissues of middle-aged rats. Amino Acids, v.46, n.5, p.1187-1195, 2014.

CHAABÈNE, M.H.; HACHANA, Y.; FRANCHINI, E.; MKAOUER, B.; CHAMARI, K. Physical and physiological profile of elite karate athletes. Sports Med., v.42, n.10, p.829-843, 2012.

COOK, D.B.; O'CONNOR, P.J.; EUBANKS, S.A.; SMITH, J.C.; LEE, M. Naturally occurring muscle pain during exercise: assessment and experimental evidence. Med. Sci. Sport Exerc., v.29, n.8, p.999-1012, 1997.

COOK, D.B.; O'CONNOR, P.J.; OLIVER, S.E.; LEE, Y. Sex differences in naturally occurring leg muscle pain and exertion during maximal cycle ergometry. Int. J. Neurosci., v.95, n.3-4, p.183-202, 1998.

DAVIS, J.K.; GREEN, J.M. Caffeine and anaerobic performance. Sports Med., v.39, n.10, p.813-832, 2009.
DOHERTY, M.; SMITH, P.M. Effects of caffeine ingestion on rating of perceived exertion during and after exercise: a meta-analysis. Scand. J. Med. Sci. Sport, v.15, n.2, p.69$78,2005$.

DUNCAN, M.J.; STANLEY, M.; PARKHOUSE, N.; COOK, K.; SMITH, M. Acute caffeine ingestion enhances strength performance and reduces perceived exertion and muscle pain perception during resistance exercise. Eur. J. Sport Sci., v.13, n.4, p.392-399, 2013.

GLAISTER, M.; MUNIZ-PUMARES, D.; PATTERSON, SD.; FOLEY, P.; MCINNES, G. Caffeine supplementation and peak anaerobic power output. Eur. J. Sport Sci., v.15, n.5, p.1-7, 2014.

GOLDSTEIN, E.R.; ZIEGENFUSS, T.; KALMAN, D.; KREIDER, R.; CAMPBELL, B.; WILBORN, C., ANTONIO, J. International society of sports nutrition position stand: caffeine and performance. J. Int. Soc. Sports Nutr., v.7, n.1, p.5, 2010.

GREER, F.; MCLEAN, C.; GRAHAM, T.E. Caffeine, performance, and metabolism during repeated Wingate exercise tests. J. Appl. Physiol., v.85, n.4, p.1502-1508, 1998.

HENDRIX, C.R.; HOUSH, T.J.; MIELKE, M.; ZUNIGA, J.M.; CAMIC, C.L.; JOHNSON, G.O.; HOUSH, D.J. Acute effects of a caffeine-containing supplement on bench press and leg extension strength and time to exhaustion during cycle ergometry. J. Strength Cond. Res., v.24, n.3, p.859$865,2010$.

JENKINS, N.T.; TRILK, J.L.; SINGHAL, A.; O'CONNOR, P.J.; CURETON, K.J. Ergogenic effects of low doses of caffeine on cycling performance. Int. J. Sport Nutr. Exerc., v.18, n.3, p.328, 2008.

LORIST, M.M.; TOPS, M. Caffeine, fatigue, and cognition. Brain Cognit., v.53, n.1, p.82-94, 2003.

MACHADO, M.; KOCH, A.J.; WILLARDSON, J.; DOS, SANTOS. F.C.; CURTY, V.M.; PEREIRA, L.N. Caffeine does not augment markers of muscle damage or leukocytosis following resistance exercise. Int. J. Sports Physiol. Perform., v.5, n.1, p.18-26, 2010. 
MOHR, M.; NIELSEN, J.J.; BANGSBO, J. Caffeine intake improves intense intermittent exercise performance and reduces muscle interstitial potassium accumulation. J. Appl. Physiol., v.111, n.5, p.1372-1379, 2011.

MORA-RODRÍGUEZ, R.; PALLARÉS, J.G.; LÓPEZSAMANES, Á.; ORTEGA, J.F.; FERNÁNDEZ-ELÍAS, V.E. Caffeine ingestion reverses the circadian rhythm effects on neuromuscular performance in highly resistance-trained men. PLoS One, v.7, n.4, e33807, 2012.

OWENS, D.S. Lifestyle Modification: Diet, Exercise, Sports and Other Issues. In: Hypertrophic cardiomyopathy. London: Springer, 2015. p.143-154.

SÖKMEN, B.; ARMSTRONG, L.E.; KRAEMER, W.J.; CASA, D.J.; DIAS, J.C.; JUDELSON, D.A.; MARESH, C.M. Caffeine use in sports: considerations for the athlete. $J$. Strength Cond. Res., v.22, n.3, p.978-986, 2008.

SPRIET, L.L. Exercise and sport performance with low doses of caffeine. Sports Med., v.44, n.2, p.175-184, 2014.

TABBEN, M.; SIOUD, R.; HADDAD, M.; FRANCHINI, E.; CHAOUACHI, A.; COQUART, J.; TOURNY-CHOLLET, C. Physiological and perceived exertion responses during international karate kumite competition. Asian J. Sports Med., v.4, n.4, p.263, 2013.
TARNOPOLSKY, M.A. Caffeine and creatine use in sport. Ann. Nutr. Metab., v.57, p.1-8, 2010.

WARREN, G.L.; PARK, N.D.; MARESCA, R.D.; MCKIBANS, K.I.; MILLARD-STAFFORD, M.L. Effect of caffeine ingestion on muscular strength and endurance: a metaanalysis. Med. Sci. Sports Exerc., v.42, n.7, p.1375-87, 2010.

WOOLF, K.; BIDWELL, W.K.; CARLSON, A.G. The effect of caffeine as an ergogenic aid in anaerobic exercise. Int. J. Sport Nutr., v.18, n.4, p.412, 2008.

YANG, A.; PALMER, A.A.; DE WIT, H. Genetics of caffeine consumption and responses to caffeine. Psychopharmacology, v.211, n.3, p.245-257, 2010.

ZHENG, X.; TAKATSU, S.; WANG, H.; HASEGAWA, H. Acute intraperitoneal injection of caffeine improves endurance exercise performance in association with increasing brain dopamine release during exercise. Pharmacol. Biochem. Behav., v.122, p.136-143, 2014.

Received for publication on $13^{\text {th }}$ July 2015 Accepted for publication on $30^{\text {th }}$ September 2016 